Narkhede, D. D. (1990). PhD Thesis, Indian Institute of Technology, Bombay 400076 , India.

SHELDRICK, G. M. (1976). SHELX76. Program for crystal structure determination. Univ. of Cambridge, England.
Stout, G. H., Rickernell, G. K. \& Sears, K. D. (1968). J. Org. Chem. 33, 4191-4200.

TAylor, R. \& Kennard, O. (1982). J. Am. Chem. Soc. 104, 5063-5070.

Acta Cryst. (1991). C47, 1925-1927

\title{
Structure of a New Benzofuran Derivative
}

\author{
By Kalyan Das and U. C. Sinha* \\ Department of Physics, Indian Institute of Technology, Bombay 400 076, India \\ S. R. Desai and S. V. Bhat \\ Department of Chemistry, Indian Institute of Technology, Bombay 400 076, India
}

and S. S. Tavale and V. G. Puranik

Physical and Structural Chemistry Division, National Chemical Laboratory, Pune 411 008, India

(Received 6 December 1990; accepted 13 February 1991)

\begin{abstract}
Epoxy-7a-hydroxy-3,7,7-trimethyl2,3,3a,7a-tetrahydro-7 $\mathrm{H}$-benzofuran-4-one, $\mathrm{C}_{11} \mathrm{H}_{14^{-}}$ $\mathrm{O}_{4}$, m.p. $=408 \mathrm{~K}, M_{r}=210 \cdot 23$, monoclinic, $P 2_{1} / c$, $a=8.230(1), \quad b=10.030(1), \quad c=12.727$ (1) $\AA$, $\beta=96 \cdot 29(1)^{\circ}, \quad V=1044 \cdot 28 \AA^{3}, \quad Z=4, \quad D_{x}=$ $1.337 \mathrm{Mg} \mathrm{m}^{-3}, \lambda($ Mo $K \alpha)=0.71069 \AA, \mu($ Mo $K \alpha)$ $=0.062 \mathrm{~mm}^{-1}, F(000)=448, T=295 \mathrm{~K}$, final $R=$ $0.045, w R=0.053$ for 1437 observed reflections. Both the rings in the molecule are cis fused. Intermolecular $\mathrm{O}-\mathrm{H} \cdots \mathrm{O}$ and $\mathrm{C}-\mathrm{H} \cdots \mathrm{O}$ interactions are observed.
\end{abstract}

Introduction. The benzofuran derivative $(A)$ (Desai, Gore \& Bhat, 1990) was found to undergo autooxidation (see below), like other 2,5-dihydrofuran derivatives (Frincke, McIntyre \& Faulkner, 1980), yielding a new crystalline product $(B)$. The structure and stereochemistry of compound $(B)$ could not be assigned unambiguously on the basis of spectroscopic studies. The crystal structure of this rather unusual new product was studied using X-ray diffraction techniques in order to establish its stereochemistry in detail.

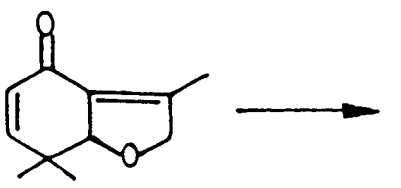

(A)

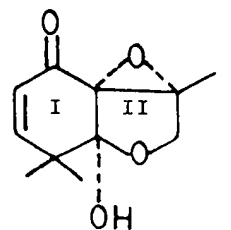

(B)

\footnotetext{
* To whom correspondence should be addressed.
}

0108-2701/91/091925-03\$03.00
Experimental. The compound was recrystallized from petroleum ether and chloroform solution as colourless crystals. A crystal of dimensions $0 \cdot 22 \times$ $0.40 \times 0.40 \mathrm{~mm}$ was used for intensity data collection with an Enraf-Nonius CAD-4 diffractometer with graphite-monochromated Mo $K \alpha \quad(\lambda=0.71069 \AA)$ radiation. The cell parameters were refined using 25 reflections in the range $11 \leq \theta \leq 18^{\circ}$. A total of 1539 reflections were scanned, $\omega / 2 \theta$ mode, in the range $0 \leq \theta \leq 23 \cdot 5^{\circ} ; 0 \leq h \leq 9,0 \leq k \leq 11,-14 \leq l \leq 14$. Three standard reflections $(356,464$ and $37 \overline{4})$ measured every $1800 \mathrm{~s}$ showed no significant intensity variation. The data were corrected for $L p$ factors and absorption effects were ignored. Equivalent reflections were merged, $R_{\text {int }}=0 \cdot 011$. Out of 1503 unique reflections, 1466 reflections with $\left|F_{o}\right| \geq$ $2 \sigma\left|F_{o}\right|$ were used for structure solution. The structure was solved by direct methods using MULTAN88 (Debaerdemaeker, Germain, Main, Refaat, Tate and Woolfson, 1988); all the non-H atoms were located from the $E$ map with the best CFOM. The refinement was by least-squares methods based on $F$ values using SHELX76 (Sheldrick, 1976). The atomic scattering factors for all the atoms were from SHELX76. The non-H atoms were refined anisotropically. All $\mathrm{H}$ atoms were located from the difference map and refined with isotropic thermal parameters. In the final refinement, 192 parameters were refined using 1437 observed reflections (with $\left|F_{o}\right| \geq 2 \cdot 5 \sigma\left|F_{o}\right|$ ). The reflections with $F_{c}>F_{o}$ and $\left|F_{o}-F_{o}\right|>4.0 \sigma\left(\left|F_{o}\right|\right)$ were omitted. Final $R=0.0452, \quad w R=0.0535$ \{where $\left.w=1.000 /\left[\sigma^{2}\left(F_{o}\right)+0.00886\left(F_{o}\right)^{2}\right]\right\}, \quad$ GOOF $=0.7923$,

(C) 1991 International Union of Crystallography 
Table 1. Atomic coordinates $\left(\times 10^{4}\right)$ and equivalent temperature factors $U_{\mathrm{eq}}\left(\AA^{2} \times 10^{3}\right)$ for non- $\mathrm{H}$ atoms with e.s.d.'s in parentheses

$$
U_{\mathrm{eq}}=\frac{1}{3} \sum_{i} \sum_{j} U_{i j} a_{i}^{*} a_{j}^{*}\left(\mathbf{a}_{i} \cdot \mathbf{a}_{j}\right) .
$$

$\begin{array}{lcccc} & x & y & z & U_{\text {eq }} \\ \mathrm{O}(1) & 8203(1) & 685(1) & 4266(1) & 43(1) \\ \mathrm{C}(2) & 7277(2) & 875(2) & 5142(2) & 47(2) \\ \mathrm{C}(3) & 5915(2) & 1811(2) & 4787(1) & 38(2) \\ \mathrm{C}(3 \mathrm{a}) & 6334(2) & 2382(1) & 3781(1) & 29(1) \\ \mathrm{O}\left(3^{\prime}\right) & 5069(1) & 1394(1) & 3782(1) & 38(1) \\ \mathrm{C}(4) & 5861(20 & 3738(2) & 3360(1) & 32(2) \\ \mathrm{O}\left(4^{\prime}\right) & 4441(1) & 4114(1) & 3277(1) & 49(1) \\ \mathrm{C}(5) & 7199(2) & 4540(2) & 3059(1) & 36(2) \\ \mathrm{C}(6) & 8738(2) & 4107(2) & 3172(1) & 36(2) \\ \mathrm{C}(7) & 9336(2) & 2797(1) & 3644(1) & 32(1) \\ \mathrm{C}(7 \mathrm{a}) & 7926(2) & 1765(1) & 3534(1) & 31(2) \\ \mathrm{O}\left(7^{\prime}\right) & 7819(2) & 1232(1) & 2518(1) & 38(1) \\ \mathrm{C}(8) & 4909(3) & 2469(3) & 5544(2) & 55(2) \\ \mathrm{C}(9) & 10796(2) & 2294(2) & 3108(2) & 45(2) \\ \mathrm{C}(10) & 9911(2) & 3065(2) & 4821(1) & 46(2)\end{array}$

Table 2. Bond distances $(\AA)$ and angles $\left(^{\circ}\right)$ with e.s.d.'s in parentheses

$\begin{array}{llll}\mathrm{C}(2)-\mathrm{O}(1) & 1.432(2) & \mathrm{O}\left(4^{\prime}\right)-\mathrm{C}(4) & 1.222(2) \\ \mathrm{C}(7 \mathrm{a})-\mathrm{O}(1) & 1.431(2) & \mathrm{C}(5)-\mathrm{C}(4) & 1.449(2) \\ \mathrm{C}(3)-\mathrm{C}(2) & 1.494(3) & \mathrm{C}(6)-\mathrm{C}(5) & 1.332(2) \\ \mathrm{C}(3 \mathrm{a})-\mathrm{C}(3) & 1.479(2) & \mathrm{C}(7)-\mathrm{C}(6) & 1.505(2) \\ \mathrm{O}\left(3^{\prime}\right)-\mathrm{C}(3) & 1.449(2) & \mathrm{C}(7 \mathrm{a})-\mathrm{C}(7) & 1.550(2) \\ \mathrm{C}(8)-\mathrm{C}(3) & 1.491(3) & \mathrm{C}(9)-\mathrm{C}(7) & 1.531(2) \\ \mathrm{O}\left(3^{\prime}\right)-\mathrm{C}(3 \mathrm{a}) & 1.437(2) & \mathrm{C}(10-\mathrm{C}(7) & 1.544(2) \\ \mathrm{C}(4)-\mathrm{C}(3 \mathrm{a}) & 1.497(2) & \mathrm{O}\left(7^{\prime}\right)-\mathrm{C}(7 \mathrm{a}) & 1.393(2) \\ \mathrm{C}(7 \mathrm{a})-\mathrm{C}(3 \mathrm{a}) & 1.513(2) & & \end{array}$

\begin{tabular}{|c|c|c|c|}
\hline$C(7 a)-O(1)-C(2)$ & $110 \cdot 3(1)$ & $C(5)-C(4)-C(3 a)$ & $115 \cdot 0(1)$ \\
\hline$C(3)-C(2)-O(1)$ & $107 \cdot 1(1)$ & $C(5)-C(4)-O\left(4^{\prime}\right)$ & $123.6(1)$ \\
\hline$C(3 a)-C(3)-C(2)$ & $105 \cdot 5(1)$ & $C(6)-C(5)-C(4)$ & $122 \cdot 1(1)$ \\
\hline$O\left(3^{\prime}\right)-C(3)-C(2)$ & $111.0(2)$ & $C(7)-C(6)-C(5)$ & $126.4(2)$ \\
\hline $\mathrm{O}\left(3^{\prime}\right)-\mathrm{C}(3)-\mathrm{C}(3 \mathrm{a})$ & $58 \cdot 8(1)$ & $C(7 a)-C(7)-C(6)$ & $109 \cdot 7(1)$ \\
\hline$C(8)-C(3)-C(2)$ & $122 \cdot 3(2)$ & $C(9)-C(7)-C(6)$ & $110 \cdot 3(1)$ \\
\hline$C(8)-C(3)-C(3 a)$ & $125.9(2)$ & $C(9)-C(7)-C(7 a)$ & $110.9(1)$ \\
\hline $\mathrm{C}(8)-\mathrm{C}(3)-\mathrm{C}\left(3^{\prime}\right)$ & $116.8(2)$ & $C(10)-C(7)-C(6)$ & $106 \cdot 7(1)$ \\
\hline$O\left(3^{\prime}\right)-C(3 a)-C(3)$ & $59 \cdot 6(1)$ & $C(10-C(7)-C(7 a)$ & $110 \cdot 5(1)$ \\
\hline$C(4)-C(3 a)-C(3)$ & $125 \cdot 9(1)$ & $C(10)-C(7)-C(9)$ & $108 \cdot 5(1)$ \\
\hline $\mathrm{C}(4)-\mathrm{C}(3 \mathrm{a})-\mathrm{O}\left(3^{\prime}\right)$ & $117 \cdot 8(1)$ & $C(3 a)-C(7 a)-O(1)$ & $104 \cdot 8(1)$ \\
\hline$C(7 a)-C(3 a)-C(3)$ & $108 \cdot 1(1)$ & $C(7)-C(7 a)-O(1)$ & $112 \cdot 5(1)$ \\
\hline $\mathrm{C}(7 \mathrm{a})-\mathrm{C}(3 \mathrm{a})-\mathrm{O}\left(3^{\prime}\right)$ & $111 \cdot 2(1)$ & $C(7-C(7 a)-C(3 a)$ & $111.4(1)$ \\
\hline$C(7 a)-C(3 a)-C(4)$ & $119 \cdot 6(1)$ & $O\left(7^{\prime}\right)-C(7 a)-O(1)$ & $107 \cdot 6(1)$ \\
\hline $\mathrm{C}(3 \mathrm{a})-\mathrm{O}\left(3^{\prime}\right)-\mathrm{C}(3)$ & $61 \cdot 6(1)$ & $\mathrm{O}\left(7^{\prime}\right)-\mathrm{C}(7 \mathrm{a})-\mathrm{C}(3 \mathrm{a})$ & $112 \cdot 4(1)$ \\
\hline $\mathrm{O}\left(4^{\prime}\right)-\mathrm{C}(4)-\mathrm{C}(3 \mathrm{a})$ & $121 \cdot 3(1)$ & $\mathrm{O}\left(7^{\prime}\right)-\mathrm{C}(7 \mathrm{a})-\mathrm{C}(7)$ & $108 \cdot 1(1)$ \\
\hline
\end{tabular}

$(\Delta / \sigma)_{\max }=0.045$. In the final difference Fourier map, $(\Delta \rho)_{\max }=0.168$ and $(\Delta \rho)_{\min }=0.259 \mathrm{e} \AA^{-3}$. A CYBER-180 was used for all computations.

Discussion. The positional parameters and the equivalent temperature factors are listed in Table 1 and the bond lengths and angles are in Table 2.* Fig. 1 represents the perspective view of the molecule (Motherwell \& Clegg, 1978).

* Lists of structure factors, anisotropic thermal parameters, $\mathrm{H}$-atom parameters and least-squares planes have been deposited with the British Library Document Supply Centre as Supplementary Publication No. SUP 53997 (10 pp.). Copies may be obtained through The Technical Editor, International Union of Crystallography, 5 Abbey Square, Chester CH1 2HU, England.
The $\mathrm{I}$ and II ring junction is cis fused with torsion angle $\mathrm{O}\left(3^{\prime}\right)-\mathrm{C}(3 \mathrm{a})-\mathrm{C}(7 \mathrm{a})-\mathrm{O}\left(7^{\prime}\right) 64.3(1)^{\circ}$. In the process of auto-oxidation, $\mathrm{O}\left(3^{\prime}\right)$ was bonded to $\mathrm{C}(3)$ and $\mathrm{C}(3 \mathrm{a})$ forming an epoxy group almost like an equilateral triangle [maximum deviation of $60^{\circ}$ angle by $\left.1.6(2)^{\circ}\right]$. The furan ring is envelope shaped with C(2) 0.281 (2) $\AA$ out of the least-squares plane passing through the remaining four atoms [maximum deviation, $0.065(2) \AA]$. The six-membered ring has a

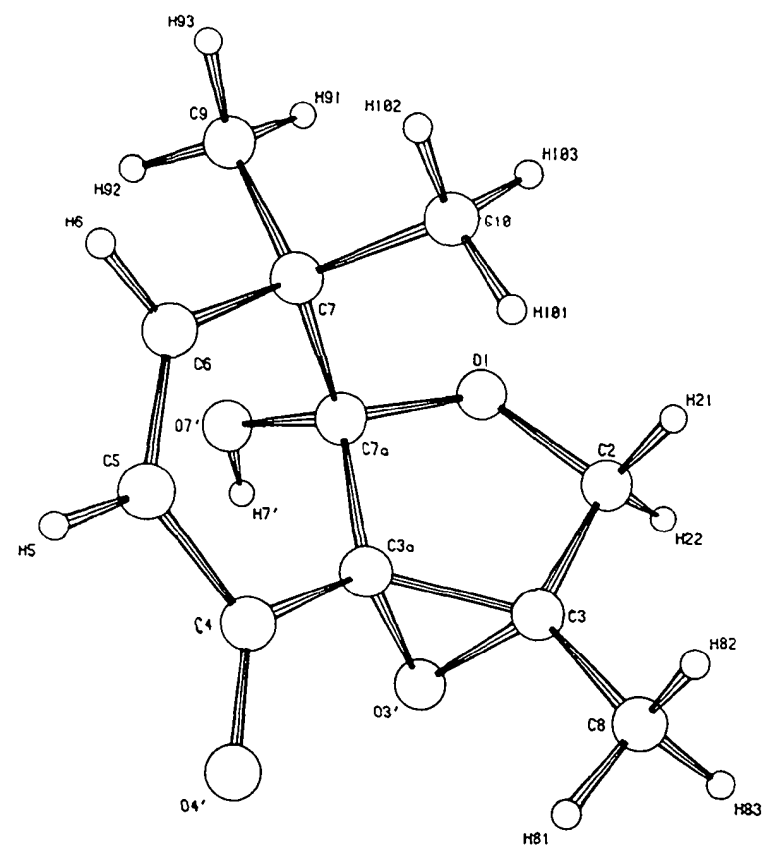

Fig. 1. Perspective view of the molecule.

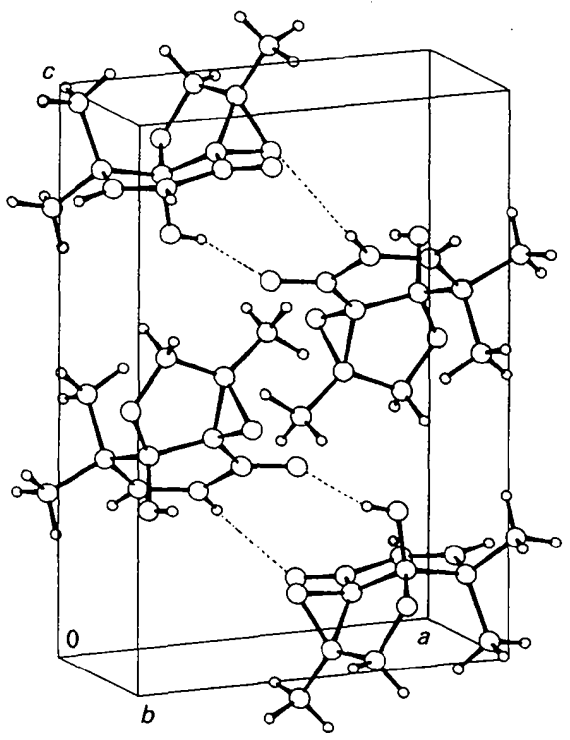

Fig. 2. Unit-cell packing diagram. 
Table 3. Important intermolecular distances $(\AA)$ and angles $\left(^{\circ}\right)$

$\begin{array}{lcccc} & \mathrm{C} \cdots \mathrm{O} / & & \mathrm{C}-\mathrm{H} \cdots \mathrm{O} / & \text { Symmetry of the } \\ & \mathrm{O} \cdots \mathrm{O} & \mathrm{H} \cdots \mathrm{O} & \mathrm{O}-\mathrm{H}^{\cdots} \mathrm{O} & \text { last atom } \\ \mathrm{O}\left(7^{\prime}\right)-\mathrm{H}\left(7^{\prime}\right) \cdots \mathrm{O}\left(4^{\prime}\right) & 2.930(2) & 2.21(2) & 157.6(12) & 1-x,-\frac{1}{2}+y, \frac{1}{2}-z \\ \mathrm{C}(2)-\mathrm{H}(21) \cdots \mathrm{O}\left(3^{\prime}\right) & 3.371(2) & 2.49(2) & 148.5(15) & 1-x,-y, 1-z \\ \mathrm{C}(5)-\mathrm{H}(5) \cdots \mathrm{O}\left(3^{\prime}\right) & 3.387(2) & 2.58(2) & 137.5(13) & 1-x, \frac{1}{2}+y, \frac{1}{2}-z \\ \mathrm{C}(9)-\mathrm{H}(93) \cdots \mathrm{O}\left(4^{\prime}\right) & 3.498(3) & 2.54(3) & 169.3(20) & 1+x, y, z\end{array}$

twisted boat conformation with $\mathrm{C}(3 \mathrm{a})$ and $\mathrm{C}(7)$ $0.316(1)$ and $0.402(1) \AA$ respectively out of the mean plane passing through $\mathrm{C}(4), \mathrm{C}(5), \mathrm{C}(6)$ and $\mathrm{C}(7 \mathrm{a})$ (within the deviation, $\pm 0.081 \AA$ ); $\mathrm{O}(4)$, connected to $\mathrm{C}(4)$, lies in this plane. The dihedral angle between the planes is $43.2(2)^{\circ}$. Variations in $\mathrm{C}-\mathrm{C}$ bond lengths and the distortion in the six-membered ring are indicative of strain. In the furan ring, the $\mathrm{O}(1)-\mathrm{C}(2)$ and $\mathrm{O}(1)-\mathrm{C}(7 \mathrm{a})$ distances are almost equal. This is in contrast to general observations of benzofuran systems which show differences in $\mathrm{C}-\mathrm{O}$ lengths (Das, Sinha, Narkhede \& Manisekharan, 1990). The methyl groups attached to $C(7)$ have an average $\mathrm{C}-\mathrm{C}$ distance of $1.538(2) \AA$ whereas the methyl $\mathrm{C}(8)$ is at a distance of 1.491 (3) $\AA$. The
$\mathrm{C}-\mathrm{H}$ distances are normal [average 0.098 (3) $\AA$ ] but $\mathrm{O}\left(7^{\prime}\right)-\mathrm{H}\left(7^{\prime}\right)$ is $0.76(2) \AA$. Important intermolecular distances are listed in Table 3 . In the crystal (Fig. 2), the molecules are linked into chains by an intermolecular $\mathrm{O}-\mathrm{H} \cdots \mathrm{O}$ bond; possible $\mathrm{C}-\mathrm{H} \cdots \mathrm{O}$ interactions are also seen (Taylor \& Kennard, 1982).

\section{References}

Das, K., Sinha, U. C., Narkhede, D. D. \& Manisekharan, T. (1990). Acta Cryst. C46, 1888-1820.

Debaerdemaeker, T., Germain, G., Main, P., Refaat, L. S., TATE, C. \& Woolrson, M. M. (1988). MULTAN88. A System of Computer Programs for the Automatic Solution of Crystal Structures from $X$-ray Diffraction Data. Univs. of York, England, and Louvain, Belgium.

Desai, S. R., Gore, V. K. \& Bhat, S. V. (1990). Tetrahedran Lett. Submitted.

Frincke, D. E., MCIntyre, D. E. \& Faulkner, D. J. (1980). Tetrahedron Lett. 21, 735-738.

Motherwell, W. D. S. \& Clegg, W. (1978). PluTO. Program for plotting molecular and crystal structures. Univ. of Cambridge, England.

SheldRICK, G. M. (1976). SHELX76. Program for crystal structure determination. Univ. of Cambridge, England.

Taylor, R. \& Kennard, O. (1982). J. Am. Chem. Soc. 104, 5063-5070.

Acta Cryst. (1991). C47, 1927-1929

\title{
Structure of 2-Benzoyl-1-phenylamino-2-(1-pyridinio)ethylene-1-thiolate
}

\author{
By Vladimir N. Nesterov, Valery E. Shklover, Yuri T. Struchkov, Yuli A. Sharanin, \\ Anatoly M. Shestopalov and Andrey S. Demerkov \\ A. N. Nesmeyanov Institute of Organoelement Compounds, USSR Academy of Sciences, 28 Vavilov St, \\ Moscow B-334, USSR
}

(Received 3 January 1990; accepted 25 February 1991)

\begin{abstract}
C}_{20} \mathrm{H}_{16} \mathrm{~N}_{2} \mathrm{OS}, M_{r}=332$, monoclinic, $C 2 / c$, $a=17.7807(12), b=8.9144(5), c=21.6994$ (11) $\AA$, $\beta=100 \cdot 465(5)^{\circ}, \quad V=3382 \cdot 2(3) \AA^{3}, \quad Z=8, \quad D_{m}=$ $1.298, \quad D_{x}=1.306 \mathrm{~g} \mathrm{~cm}^{-3}, \quad \lambda($ Mo $K \alpha)=0.71069 \AA$, $\mu=2.004 \mathrm{~cm}^{-1}, \quad F(000)=1392, \quad T=293 \mathrm{~K}$, $R=0.037, w R=0.046$ for 1555 independent reflections. The molecule has a $Z$ configuration relative to the formally double $\mathrm{C}(1)=\mathrm{C}(2)$ bond. The negative charge is delocalized over the conjugated ylide $\mathrm{S} \cdots \mathrm{C}(1) \cdots \mathrm{C}(2) \cdots \mathrm{C}(3) \cdots \mathrm{O}$ moiety, the positive charge is N(1)
\end{abstract}

localized at the $\mathrm{N}$ atom of the pyridinium ring.

Introduction. 2-Benzoyl-1-phenylamino-2-(1-pyridinio)ethylene-1-thiolate (I) has been obtained by

0108-2701/91/091927-03\$03.00 interaction of $\mathrm{N}$-phenacylpyridinium bromide with phenyl isothiocyanate in the presence of equimolar amounts of triethylamine in methanol at room temperature.

The data from UV, IR and NMR spectroscopy do not allow the unambiguous assignment of configuration ( $E$ or $Z$ ) of molecule (I) relative to the formal double $\mathrm{C}(1)=\mathrm{C}(2)$ bond, so the X-ray structural analysis of the compound (I) was performed.

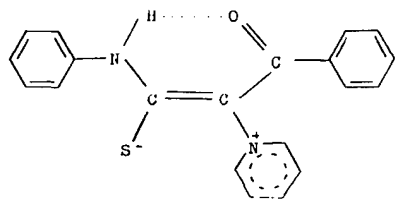

(I)

(C) 1991 International Union of Crystallography 